\title{
Early sport dropout: High performance in early years in young athletes is not related with later success Abandono deportivo precoz: el alto rendimiento en edades tempranas no garantiza el éxito deportivo en la edad adulta \\ *Pedro Ángel Latorre-Román, **Felipe Garcia Pinillos, *Juan López Robles \\ *Universidad de Jaén (España), **Universidad de La Frontera (Temuco, Chile)
}

\begin{abstract}
Objective: to analyze the career (based on the Royal Spanish Athletics Federation (RFEA) rankings) and/or dropout rates of the top 10 athletes aged14 to 19 years, during the period 2004-2014. Equipment and methods: Top 10 finishers in different athletic disciplines in the time range from 2004 to 2014 were selected after consulting the yearly national ranking database of the RFEA, published on its website (www.rfea.es). Results: There were 1,144 participants, 594 males and 550 females. All athletes, at the time of their presence in the top 10 in 2004 , were between 14-19 years old, belonging to the following categories: cadet (14-15 years), youth (16-17 years) and juniors (19-19 years), in both sexes. There was a significant reduction of athletes in the top 10 from 2004 to 2014. Of the 1,144 athletes taken into consideration in 2004, 1,104 (96.50\%) were considered as dropouts from high performance in 2014: 543 (98.72\%) were women, and 561 (94.45\%) were men. From the overall analysis and taking into account the athletic disciplines, sprint and hurdles in males (99.4\%), and middle/long running and walks in females (100\%), showed the highest percentage of dropouts. These results oppose the idea that success at a young age (i.e., the top 10 ranking) ensures later success. Therefore, in athletics where peak performance is achieved close to the senior category, early specialization should be questioned. Keywords: athletic performance, burnout, early specialization.
\end{abstract}

Resumen. Objetivo: analizar la carrera deportiva (basándonos en los rankings reportados por la Real Federación Española de Atletismo - RFEA) y las tasas de abandono de los atletas encuadrados en el top 10, con una edad entre 14-19 años, entre los años 2004 a 2014 . Método: basándonos en la base de datos aportada por la RFEA a través de su web (www.rfea.es) desde 2004, han sido seleccionados el top 10 en diferentes disciplinas atléticos entre los años 2004-2014. Resultados: participaron 1144 participantes, 594 varones y 550 mujeres. Todos los atletas, en el momento de su presencia en el top 10 en 2004 tenían entre 14-19 años, y pertenecían a las categorías: cadetes (14-15 años), juvenil (16-17 años) y junior (18-19 años) en ambos sexos. Se halló una reducción significativa de atletas presentes en el top 10, entre 2004-2014. De los 1144 atletas considerados en 2004, 1104 (96.50\%) abandonaron el top10 en 2014: 543 (98.72\%) fueron mujeres, y 561 (94.45\%) hombres. Considerando las disciplinas atléticas, las pruebas de sprint y vallas (99.4\%) y la carrera de medio fondo y marcha en mujeres (100\%) mostraron la mayor tasa de abandono. Conclusión: estos resultados muestran que el éxito a edades jóvenes no asegura el rendimiento en etapas posteriores del desarrollo. Por tanto, en disciplinas deportivas en las que el pico de rendimiento se alcanza a edad adulta, la especialización precoz se debe poner en duda.

Palabras clave: abandono deportivo, especialización precoz, rendimiento atlético.

\section{Introduccion}

Over the past 15 years, there has been an increase in early training in a single sport in the young (Feeley, Agel, \& LaPrade, 2015). Even today, many children at relatively young ages are introduced to sport specialization (Malina, 2010). There are several factors that contribute to the desire of young athletes to specialize in a single sport, including the pursuit of scholarships or professional contracts, being labeled as talented by parents or coaches, the retailing industry and media reports (Mostafavifar, Best, \& Myer, 2013). Further, many coaches, parents and children believe that the best way to achieve the elite level in sports is through participation in only one sport from an early age; however, this may reduce opportunities to participate in several sports and can lead to less development of sports skills (Myer et al., 2015). Thereby, sports specialization in early to middle childhood, intense training in one sport while excluding others, has become increasingly common; however, there is a concern that sports specialization before adolescence can be a negative for young athletes (Jayanthi, Pinkham, Dugas, Patrick, \& LaBella, 2013).

Taken together, a controversial question within sports initiation in children makes reference to early sport specialization versus early diversification (which includes different sport experiences during childhood). Côté, Baker, \& Abernethy (2007) showed two models of sport initiation by distinguishing between learning activities that may be regarded as organized activities and those that may be more considered as play. In the organized activities, the main purpose is skill development and performance enhancement, and the play activities contribute to the acquisition of expertise through enjoyment. After the sampling years (as engaging in a variety of sports during childhood), the children can continue to participate in recreational sport (recreational years, ages $13+$ ) or in the sport performance (specializing years, ages 13 to 15 ; investment years, ages 16+); a third option consists of elite performan-

Fecha recepción: 17-05-17. Fecha de aceptación: 03-08-17

Felipe Garcia Pinillos

egarpi@gmail.com ce through early specialization, which could harm the health of athletes and enjoyment of sports (Côté et al., 2007).

After analyzing several authors, Côté, Lidor, \& Hackfort (2009) indicates that the current trends about youth sport activities are characterized by institutionalization, elitism and early selection or specialization; moreover, early specialization is not always consistent with children's motivation to participate in sports. Of high school athletes between the ages of 13 and 18 years, 36.4\% showed high sport specialization, which most likely resulted in a history of knee injuries due to overuse (Bell et al., 2016). Likewise, specialization is positively correlated with increased serious overuse injury risk, due to the following factors: year-round single-sport training, participation in more competition, decreased age-appropriate play and involvement in individual sports that require the early development of technical skills (Myer et al., 2015).

In addition, early involvement in international events and selection of talent during early ages is not a prerequisite of success (Barreiros \& Fonseca, 2012). Thereby, early success in young sports is no guarantee of later success in elite sports (Malina, 2010). Likewise, early sport specialization does not cause competitive improvements in relation to athletes who participate in multiple sports and may put the young athlete at risk for overuse injuries (Feeley et al., 2015). Moreover, some researchers showed that an early sport diversification does not disadvantage athletes in acquiring expertise and is important for intrinsic motivation and skill transferability (Baker, Cobley, \& Fraser Thomas, 2009). Therefore, early sport specialization has not been shown to improve future athletic performance; however, it is detrimental both physically and emotionally. Moreover, there are long-term consequences on adulthood for the athlete who specializes at a young age (Smucny, Parikh, \& Pandya, 2015).

The transition to elite sport is described by athletes as the most difficult and many of them confess that it failed (Chamorro \& Oliva, 2016). In this regard, the lack of time and academic demands are causes of sports abandonment of adolescents (Capdevila Seder, Bellmunt Villalonga, \& Hemando Domingo, 2015). Information on the effectiveness of early sport specialization, along with high sport performance and 
long-term success of children athletes, is sparse. Therefore, the purpose of this study was to analyze the career (based on the RFEA rankings) and/or dropout rate of the top 10 athletes, 14 to 19 years old, from 2004 to 2014. Specifically, we wanted to investigate whether presence in the top 10 ranking at a younger age could limit achieving the top 10 ranking in the senior category stage where maximum performance is reached (Hollings, Hopkins, Hume, \& Bosch, 2014). Moreover, a second aim of this study was to assess the influence of other variables, such as the sex of the athlete and athletic discipline practised, with the purpose to better understand if participation in the top 10 at a younger age is positive to achieve success in the senior category or is related to early dropout.

\section{Method}

This is a longitudinal prospective study focused on determining whether early high performance (and thereby, early specialization) ensures a late high performance (i.e., in senior category). Additionally, the current study analyses the influence of other influencing variables on this such as sex and athletic discipline.

\section{Procedure}

By using the database of the national ranking of each year of the Royal Spanish Athletics Federation (RFEA), published on its website (www.rfea.es), the top ten finishers of different athletic disciplines have been selected between 2004 and 2014. Of the 1144 participants described, 594 are males and 550 females. All athletes, at the time of their presence in the top ten in 2004, were between 14-19 years old and of the categories: cadet (14-15 years), youth (16-17 years) and juniors (19-19 years), as well as in both sexes: male and female.

Data were retrieved from the online website source (www.rfea.es), and the national ranking in different categories and athletic disciplines of the outdoor season have been published since 2004. The top 10 athletes from the cadet, youth and junior categories, and from both sexes, from 2004 to 2014 in the senior category, in the specialties of running, jumping and throwing, were selected. All was in the outdoor season. We considered as dropouts from high performance, athletes who were not present in the top 10 of the official rankings published by RFEA in 2014.

\section{Statistical analysis}

Data from this study were analyzed using the SPSS statistical program V.19.0 forWindows(SPSS Inc., Chicago, USA). The significance level was set at $\mathrm{p}<0.05$, with a confidence level of $95 \%$. The data are shown in descriptive statistics of frequencies and percentages. The analysis of data between 2004 and 2014 was performed using the McNemar test.

\section{Results}

Table 1 shows the results in relation to male athletes in different athletic disciplines. There is a significant reduction of athletes in the top 10 from 2004 to 2014 . Likewise, Table 2 shows similar results in female athletes.
Figure 1 shows the reduction total in male and female athletes of their presence in the top 10 from 2004 to 2014, in all athletic disciplines. Of the 1144 athletes taken into consideration in 2004, 1104 (96.50\%) were considered as dropouts from high performance in 2014; 543 (98.72\%) were women and 561 (94.45\%) men. From the overall analysis, and taking into account the athletic disciplines, the sprint and hurdles in males (99.4\%) and middle/long running and walks in females (100\%) showed the highest percentage of dropouts.

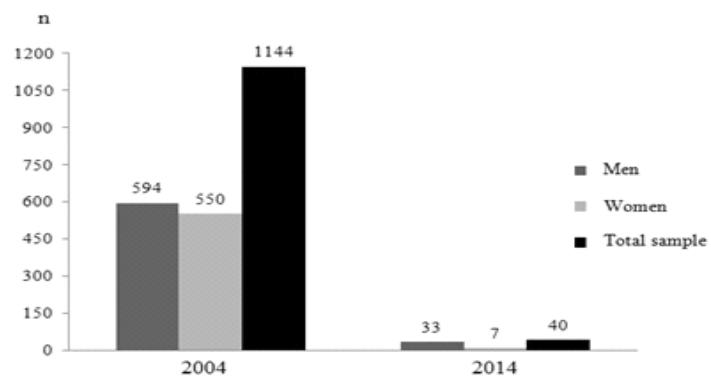

Figure 1. The reduction total of their presence in the top 10 in male and female athletes, from 2004 to 2014, in all athletics disciplines.

\section{Discussion}

The main finding of this study shows that high performance in early years in young athletes is not related to later success, where peak performance is achieved around the senior category. Further, women showed greater dropout rates than men. In all athletic specialties, there was a high dropout rate, both for women and men.

Previous studies found similar results. These results are in accordance with Barreiros, Côté, \& Fonseca (2014), which showed that only a third of international pre-junior athletes reappeared as senior athletes, confirming the difficulties of predicting late success based on early identification and selection. Therefore, few children who specialize in sports at young ages achieved elite levels; the majority dropped out along the way (Malina, 2010). Barreiros \& Fonseca (2012) showed that it is possible to attain status as an international athlete without early success. Likewise, Pizzuto, Bonato, Vernillo, La Torre, \& Piacentini (2016) analyzed if participation at the World Junior Championships (WJC) in the middle and long-distance track events is a prerequisite to success at a senior level, and a result more relevant showed that in 2015, $61 \%$ of finalists in the 2002 WJC were not present in the IAAF rankings. Further, the sport dropout rate increases over time, after 8 and 14 years of follow-up. The sport dropout rate in young athletes was 56.6\% and 81.5\%, respectively: 51.5\%-79.6\% in males and 67.3\%87.5\% in females (Enoksen \& Eystein, 2011).

In relation to sex, the girls showed a higher dropout percentage compared to boys, confirming the results of previous studies (Enoksen \& Eystein, 2011; Pizzuto et al., 2016). For more important reasons for dropouts in relation to sex, Molinero, Salguero, Concepcin, Alvarez, \& Marquez (1982) showed that girls placed greater emphasis than boys on «had other things to do» and considered less important reasons like «not interesting to me». Further, because the girls reach their maximum athletic performance earlier than boys, early specialization may lead to stagnation in performance and sport dropout; another reason for high

\begin{tabular}{|c|c|c|c|c|c|c|c|c|c|c|c|c|c|c|c|c|c|c|}
\hline & \multicolumn{3}{|c|}{ Long distance } & \multicolumn{3}{|c|}{ Middle/long } & \multicolumn{3}{|c|}{ Sprint and hurdles } & \multicolumn{3}{|c|}{ Walks } & \multicolumn{3}{|c|}{ Jumps } & \multicolumn{3}{|c|}{ Throws } \\
\hline & 2004 & 2014 & p-value & 2004 & 2014 & $p$-value & 2004 & 2014 & $\mathrm{p}$-value & 2004 & 2014 & $\mathrm{p}$-value & 2004 & 2014 & $\mathrm{p}$-value & 2004 & 2014 & $\mathrm{p}$-value \\
\hline Cadet & $20(100)$ & 1(5) & $<0.001$ & $20(100)$ & $2(10)$ & $<0.001$ & $140(100)$ & $1(2.5)$ & $<0.001$ & $14(100)$ & $0(0)$ & $<0.001$ & $40(100)$ & $1(2.5)$ & $<0.001$ & $40(100)$ & $4(10)$ & $<0.001$ \\
\hline Youth & $30(100)$ & $2(6.66)$ & $<0.001$ & $20(100)$ & $1(5)$ & $<0.001$ & $160(100)$ & $0(0)$ & $<0.001$ & $20(100)$ & $0(0)$ & $<0.001$ & $40(100)$ & $2(5)$ & $<0.001$ & $40(100)$ & $5(12.5)$ & $<0.001$ \\
\hline Junior & $40(100)$ & $2(5)$ & $<0.001$ & $20(100)$ & $2(10)$ & $<0.001$ & $150(100)$ & $0(0)$ & $<0.001$ & $20(100)$ & $3(15)$ & $<0.001$ & $40(100)$ & $5(12.5)$ & $<0.001$ & $40(100)$ & $2(5)$ & $<0.001$ \\
\hline Total & $90(100)$ & $5(5.5)$ & $<0.001$ & $60(100)$ & $5(8.33$ & $<0.001$ & $1 \quad 150(100)$ & $1(0.6)$ & $<0.001$ & $54(100)$ & $3(5.55)$ & $<0.001$ & $120(100)$ & $8(6.66)$ & $<0.001$ & $120(100)$ & $11(9.16)$ & $<0.001$ \\
\hline \multicolumn{19}{|l|}{$\begin{array}{l}\text { Table } 2 . \\
\text { Top 10, }\end{array}$} \\
\hline & \multicolumn{3}{|c|}{$\begin{array}{l}4 \text { to } 2014 \text {, in fem } \\
\text { Long distance }\end{array}$} & \multicolumn{3}{|c|}{$\begin{array}{l}\text { Middle/long } \\
\text { Midonte ant }\end{array}$} & \multicolumn{3}{|c|}{$\begin{array}{l}\text { nes. Data shown in } n \\
\text { Sprint and hurdles }\end{array}$} & \multicolumn{3}{|c|}{ Walks } & \multicolumn{3}{|c|}{ Jumps } & \multicolumn{3}{|c|}{ Throws } \\
\hline & 2004 & 2014 & p-value & 2004 & 2014 & p-value & 2004 & 2014 & p-value & 2004 & 2014 & $\mathrm{p}$-value & 2004 & 2014 & p-value & 2004 & 2014 & p-value \\
\hline Cadet & $10(100)$ & $1(10)$ & 0.004 & $20(100)$ & 0 & $<0.001$ & $40(100)$ & $1(02.5)$ & $<0.001$ & $20(100)$ & 0 & $<0.001$ & $40(100)$ & $1(2.5)$ & $<0.001$ & $40(100)$ & 0 & $<0.001$ \\
\hline Younth & $20(100)$ & 0 & $<0.001$ & $20(100)$ & 0 & $<0.0015$ & $50(100)$ & $1(2.0)$ & $<0.001$ & $20(100)$ & 0 & $<0.001$ & $40(100)$ & $0(0.0)$ & $<0.001$ & $40(100)$ & 0 & $<0.001$ \\
\hline Junior & $30(100)$ & $1(3.33)$ & $<0.001$ & $20(100)$ & 0 & $<0.0015$ & $50(100)$ & $0(0.0)$ & $<0.001$ & $10(100)$ & 0 & $<0.001$ & $40(100)$ & $1(2.5)$ & $<0.001$ & $40(100)$ & $3(7.5)$ & $<0.001$ \\
\hline Total & $60(100)$ & $2(3.33)$ & $<0.001$ & $60(100)$ & 0 & $<0.001$ & $140(100)$ & $2(1.42)$ & $<0.001$ & $50(100)$ & 0 & $<0.001$ & $120(100)$ & $2(0.83)$ & $<0.001$ & $120(100)$ & $1(2.5)$ & $<0.001$ \\
\hline
\end{tabular}


dropout rates in women is the traditional patterns of sex roles in society (Enoksen \& Eystein, 2011).

Broadly, the participants in individual sports noted «my skills did not improve», «did not like to compete» and «not able to be with my friends» as more important reasons for sport dropout (Molinero et al., 1982). Especially in athletes, the frequency of injuries, stagnation in performance, educational requirements and a lack of motivation were important reasons for why relatively many talented track and field athletes dropped out at an early age (Enoksen \& Eystein, 2011).

For most sports, the intense training and specialization before puberty are not necessary to achieve the elite level; however, the sport specialization leads to higher rates of injury, increased psychological stress and early sport dropout (Jayanthi et al., 2013). There is a significant association between the number of sports practised at 11, 13 and 15 years and the standard of competition between 16 and 18 years; thus, the children who compete in three sports are significantly more likely to compete at a national level between the ages of 16 and 18 than those who practised only one sport (Bridge \& Toms, 2012). In this regard, the boys aged 10-12 years, who spent many hours in various sports, showed greater fitness than boys specializing in a single sport (Fransen et al., 2012). Therefore, early diversification in sports is linked to a longer sport career and for long-term sport involvement, and it does not hinder elite sport participation in sports where a greater performance is achieved after maturation (Côté et al., 2009). Likewise, LaPrade et al. (2016) showed that there is no evidence that children will benefit from early sport specialization in the majority of sports; thus, early multisport practice will not keep young athletes from long-term competitive athletic success.

To develop elite-level athletes, not only the acquisition of sport skills is necessary but also optimizing the health of young athletes through continued participation in sports (Côté et al., 2007). Children who participate for more than 16 hours per week in intense training of specialized sports activities should be monitored for markers of burnout, overuse injury or decrements in performance due to overtraining (Myer et al., 2015). Therefore, the intense training and specialization in most sports should be delayed until late adolescence to reduce the risk for injury and adverse psychological stress (Jayanthi et al., 2013). Thereby, the sport career organized with less training at early ages and specialization later seems more beneficial for the young in sports and athletics (Moesch, Elbe, Hauge, \& Wikman, 2011).

The main limitation in this study is it has considered only the top 10 ; therefore, some athletes could have been near to top 10 , which could not be considered as an actual dropout. Finally, another limitation was that this study has not differentiated each athletic specialty individually. Future studies must address these limitations.

\section{Conclusions}

To sum up, these results do not confirm that success at a young age (i.e., the top 10 ranking) ensures later success. In a sex comparison, women showed greater dropout rates than men, although a high dropout rate was found in all athletic specialties both for women and men. In athletics, where peak performance is achieved around the senior category, high performance in early years in young athletes is not related to later success, therefore, early specialization should be questioned

From a practical point of view, this study supports that the intense training and specialization in most sports should be delayed until late adolescence to reduce the risk for injury and adverse psychological stress and, thereby, the sport career organized with less training at early ages and specialization later seems more beneficial for the young in sports and athletics.

\section{Disclosure of interests}

The authors declare that they have no competing interest.

\section{References}

Baker, J., Cobley, S., \& FraserThomas, J. (2009). What do we know about early sport specialization? Not much! High Ability Studies, 20(1), 77-89. http:// doi.org/10.1080/13598130902860507

Barreiros, A., Côté, J., \& Fonseca, A. M. (2014). From early to adult sport success: Analysing athletes' progression in national squads. European Journal of Sport Science, 14(sup1), S178-S182. http://doi.org/10.1080/17461391.2012.671368

Barreiros, A. N., \& Fonseca, A. M. (2012). A Retrospective Analysis of Portuguese Elite Athletes' Involvement in International Competitions. International Journal of Sports Science and Coaching, 7(3), 593-600. http://doi.org/10.1260/17479541.7.3.593

Bell, D. R., Post, E. G., Trigsted, S. M., Hetzel, S., McGuine, T. a, \& Brooks, M. A. (2016). Prevalence of Sport Specialization in High School Athletics: A 1Year Observational Study. The American Journal of Sports Medicine, 44(6), 1469-74. http://doi.org/10.1177/0363546516629943

Bridge, M. W., \& Toms, M. R. (2012). The specialising or sampling debate: a retrospective analysis of adolescent sports participation in the UK. Journal of Sports Sciences, 31, 1-10. http://doi.org/10.1080/02640414.2012.721560

Capdevila Seder, A., Bellmunt Villalonga, H., \& Hernando Domingo, C. (2015). Estilo de vida y rendimiento académico en adolescentes: comparación entre deportistas y no-deportistas. Retos: nuevas tendencias en educación física, deporte y recreación, 27, 28-33.

Chamorro, J. L., \& Oliva, D. S. (2016). ¿ Jugaré en la élite? Expectativas de llegar a profesional y su relación con la motivación en jóvenes jugadores de fútbol. Retos: nuevas tendencias en educación física, deporte y recreación,29,153156.

Côté, J., Baker, J., \& Abernethy, B. (2007). Practice and play in the development of sport expertise. Handbook of Sport Psychology, 3, 184-202.

Côté, J., Lidor, R., \& Hackfort, D. (2009). To Sample or to Specialize? ISSP Position Stand: To Sample or to Specialize? Seven Postulates About Youth Sport Activities that lead to continued participation and elite performance. International Journal of Sport and Exercise Psychology, 9,7-17. http://doi.org/ 10.1080/1612197X.2009.9671889

Enoksen, E., \& Eystein. (2011). Drop-out rate and drop-out reasons among promising Norwegian track and field athletes: a 25 year study. Scandinavian Sport Studies Forum 2,19-43.

Feeley, B. T., Agel, J., \& LaPrade, R. F. (2015). When Is It Too Early for Single Sport Specialization? The American Journal of Sports Medicine, 44(1), 234241. http://doi.org/10.1177/0363546515576899

Fransen, J., Pion, J., Vandendriessche, J., Vandorpe, B., Vaeyens, R., Lenoir, M. \& Philippaerts, R. M. (2012). Differences in physical fitness and gross motor coordination in boys aged 6-12 years specializing in one versus sampling more than one sport. Journal of Sports Sciences, 30(4), 379-386. http://doi.org/ 10.1080/02640414.2011.642808

Hollings, S. C., Hopkins, W. G, Hume, P. A., \& Bosch, A. (2014). Age at Peak Performance of Successful Track \&amp; Field Athletes. International Journal of Sports Science \& Coaching, 9(4),651-661.

Jayanthi, N., Pinkham, C., Dugas, L., Patrick, B., \& LaBella, C. (2013). Sports Specialization in Young Athletes: Evidence-Based Recommendations. Sports Health: A Multidisciplinary Approach, 5(3), 251-257. http://doi.org/10.1177/ 1941738112464626

LaPrade, R. F., Agel, J., Baker, J., Brenner, J. S., Cordasco, F. A., Côté, J., ... Provencher, M. T. (2016). AOSSM Early Sport Specialization Consensus Statement. Orthopaedic Journal of Sports Medicine, 4(4),1-8. http://doi.org/ $10.1177 / 2325967116644241$

Malina, R. M. (2010). Early sport specialization: Roots, effectiveness, risks. Current Sports Medicine Reports, 9(6), 364-371. http://doi.org/10.1249/ JSR.0b013e3181fe3166

Moesch, K., Elbe, A. M., Hauge, M. L. T., \& Wikman, J. M. (2011). Late specialization: the key to success in centimeters, grams, or seconds (cgs) sports. Scandinavian Journal of Medicine and Science in Sports, 21(6),1-9. http:// doi.org/10.1111/j.1600-0838.2010.01280.x

Molinero, O., Salguero, A., Concepcin, T., Alvarez, E., \& Marquez, S. (1982). Dropout Reasons in Young Spanish Athletes/ : Relationship to Gender, lype of Sport and Level of Competition. Journal of Sport Behavior, 29(3), 255269.

Mostafavifar, A. M., Best, T. M., \& Myer, G D. (2013). Early sport specialisation, does it lead to long-term problems? British Journal of Sports Medicine, 47(17), 1060-1061. http://doi.org/10.1136/bjsports-2012-092005

Myer, G. D., Jayanthi, N., Difiori, J. P., Faigenbaum, A. D., Kiefer, A. W., Logerstedt, D., \& Micheli, L. J. (2015). Sport Specialization, Part I: Does Early Sports Specialization Increase Negative Outcomes and Reduce the Opportunity for Success in Young Athletes? Sports Health: A Multidisciplinary Approach, 7(5), 437-442.

Myer, G. D., Jayanthi, N., DiFiori, J. P., Faigenbaum, A. D., Kiefer, A. W., Logerstedt, D., \& Micheli, L. J. (2015). Sports Specialization, Part II: Alternative Solutions to Early Sport Specialization in Youth Athletes. Sports Health, 8(1), 65-73. http://doi.org/10.1177/1941738115614811

Pizzuto, F., Bonato, M., Vernillo, G., La Torre, A., \& Piacentini, M. F. (2016). Are the World Junior Championship Finalists for Middle and Long-Distance Events Currently Competing at International Level? International Journal of Sports Physiology and Performance, 1-19,316-321. http://doi.org/10.1123/ ijspp.2015-0717

Smucny, M., Parikh, S. N., \& Pandya, N. K. (2015). Consequences of Single Sport Specialization in the Pediatric and Adolescent Athlete. Orthopedic Clinics of North America, 46(2), 249-258http://doi.org/10.1016/j.ocl.2014.11.004 